\title{
Article \\ Electrochemical Sensing of Idarubicin-DNA Interaction Using Electropolymerized Azure B and Methylene Blue Mediation
}

\author{
Anastasia Goida ${ }^{1}$, Yurii Kuzin ${ }^{1}(\mathbb{D})$, Vladimir Evtugyn ${ }^{2}$, Anna Porfireva ${ }^{1}$ (D), Gennady Evtugyn ${ }^{1,3}$ (D) \\ and Tibor Hianik $4, * \mathbb{D}$
}

1 A.M. Butlerov' Chemistry Institute, Kazan Federal University, 18 Kremlevskaya Street, 420008 Kazan, Russia; a.goida@mail.ru (A.G.); yzinkyra@mail.ru (Y.K.); anna.porfireva@kpfu.ru (A.P.); gennady.evtugyn@kpfu.ru (G.E.)

2 Interdisciplinary Center of Analytical Microscopy, Kazan Federal University, 18 Kremlevskaya Street, 420008 Kazan, Russia; vevtugyn@gmail.com

3 Analytical Chemistry Department, Chemical Technology Institute, Ural Federal University, 19 Mira Street, 620002 Ekaterinburg, Russia

4 Department of Nuclear Physics and Biophysics, Comenius University, Mlynska dolina F1, 84248 Bratislava, Slovakia

* Correspondence: tibor.hianik@fmph.uniba.sk

check for

updates

Citation: Goida, A.; Kuzin, Y.;

Evtugyn, V.; Porfireva, A.; Evtugyn,

G.; Hianik, T. Electrochemical

Sensing of Idarubicin-DNA

Interaction Using Electropolymerized

Azure B and Methylene Blue

Mediation. Chemosensors 2022, 10, 33.

https://doi.org/10.3390/

chemosensors10010033

Academic Editor: Rosanna Ciriello

Received: 16 December 2021

Accepted: 11 January 2022

Published: 13 January 2022

Publisher's Note: MDPI stays neutral with regard to jurisdictional claims in published maps and institutional affiliations.

Copyright: (C) 2022 by the authors. Licensee MDPI, Basel, Switzerland. This article is an open access article distributed under the terms and conditions of the Creative Commons Attribution (CC BY) license (https:// creativecommons.org/licenses/by/ $4.0 /)$.

\begin{abstract}
A highly sensitive electrochemical DNA sensor for detection of the chemotherapeutic drug idarubicin mediated by Methylene blue (MB) has been developed. DNA from fish sperm has been immobilized at the electropolymerized layers of Azure B. The incorporation of MB into the DNA layers substantially increased the sensor sensitivity. The concentration range for idarubicin determination by cyclic voltammetry was from $1 \mathrm{fM}$ to $0.1 \mathrm{nM}$, with a limit of detection (LOD) of $0.3 \mathrm{fM}$. Electrochemical impedance spectroscopy (EIS) in the presence of a redox probe $\left(\left[\mathrm{Fe}(\mathrm{CN})_{6}\right]^{3-/ 4-}\right)$ allowed for the widening of a linear range of idarubicin detection from $1 \mathrm{fM}$ to $100 \mathrm{nM}$, retaining LOD $0.3 \mathrm{fM}$. The DNA sensor has been tested in various real and artificial biological fluids with good recovery ranging between $90-110 \%$. The sensor has been successfully used for impedimetric idarubicin detection in medical preparation Zavedos ${ }^{\circledR}$. The developed DNA biosensor could be useful for the control of the level of idarubicin during cancer therapy as well as for pharmacokinetics studies.
\end{abstract}

Keywords: idarubicin; Azure B; electropolymerization; DNA sensor; voltammetry; electrochemical impedance spectroscopy; AFM; human urine

\section{Introduction}

Idarubicin (IDA (1)) is a cytostatic anthracycline chemotherapy drug with a broad action spectrum. In 1990, the U.S. Food and Drug Administration (FDA) approved IDA for the treatment of acute myelogenous leukemia. It is also used in lung, ovarian and advanced breast cancer, multiple myeloma and non-Hodgkin's lymphoma therapy [1-3]. IDA is a semisynthetic derivative of daunorubicin (4-demethoxydaunorubicin) and at least twice as potent as daunorubicin in different cancer cell lines. IDA induces a faster and higher apoptosis rate compared with daunorubicin [4]. IDA was the first anthracycline chemotherapy drug admitted for oral use because of its enhanced lipophilicity [5]. The taking of anthracycline antibiotics often leads to serious side effects. Among them, cardiotoxicity is most dangerous. For these reasons, it is strictly necessary to control the level of chemotherapy agents in biological fluids (urine, blood plasma, blood serum, and whole blood) for adequate correction of personal intake and pharmacokinetics monitoring. To date, IDA is determined by several physical methods, e.g., spectrofluorometry [6], high performance liquid chromatography (HPLC) with UV and fluorescence detection [7] and electroanalytical techniques [8,9] (see also review [10]). Being sensitive and universal, such methods require sophisticated equipment, complicated and time-consuming sample treatment, and skilled labor staff. 


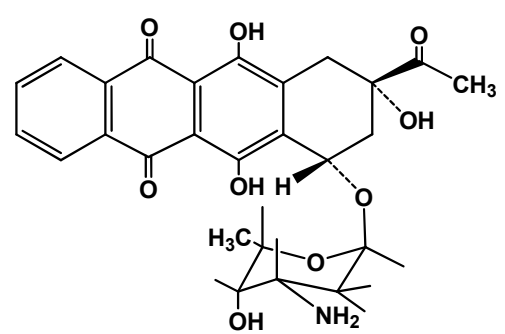

The use of DNA as a recognition element offers new opportunities in the development of biosensors for antitumor drug determination [11-14]. In them, specific DNA-drug complexation is considered as a model of target interactions in a living being. Changes in the DNA configuration, charge distribution and coordination at the transducer interface are monitored using spectroscopic or electrochemical tools. The DNA preparations for such purposes are commercially available and do not require specific nucleotide sequences like the DNA probes used in the hybridization detection.

The use of electropolymerized materials in biosensor design is mainly directed at the mediation of electron transfer and in electric wiring bioreceptors to detect recognition events via changes in the appropriate currents and charge transfer resistance. Electroconductive polymers, e.g., polyaniline [15,16], polythiophene [17] and polypyrrole [18], are used in such biosensors. Their implementation in the biosensor assembly diminishes the resistance of the interface and simplifies the immobilization of biopolymers via electrostatic interactions. In the case of the detection of small molecules by their binding with DNA molecules, the above-mentioned polymers mainly responded to the analyte binding by changes in redox equilibrium and appropriate peak currents on voltammograms. Meanwhile these changes can be partially compensated for by cooperative transfer of counter ions (doping-dedoping reactions). Besides this, electroconductivity of the hybrid DNA-polymer coatings can be altered by unexpected changes in the $\mathrm{pH}$ and ionic strength of the electrolytes.

In this respect, the use of redox active but not electroconductive polymers as matrices for DNA immobilization and signal generation can be advantageous. Recently, we have shown that the electropolymerization of phenazine and acridine dyes, e.g., proflavine [19], Azure A and Azure B [20,21], followed by DNA adsorption results in high sensitivity of the electrochemical properties of the coatings to DNA intercalation and damage. Indeed, they showed high sensitivity in anthracycline determination, though their signals were limited by the solubility of monomers in water and the moderate efficiency of electropolymerization protocol. In this work, we describe for the first time the determination of idarubicin with DNA sensors based on electropolymerized Azure B. The protocol of the biosensor assembly and signal measurement is schematically outlined in Figure 1.
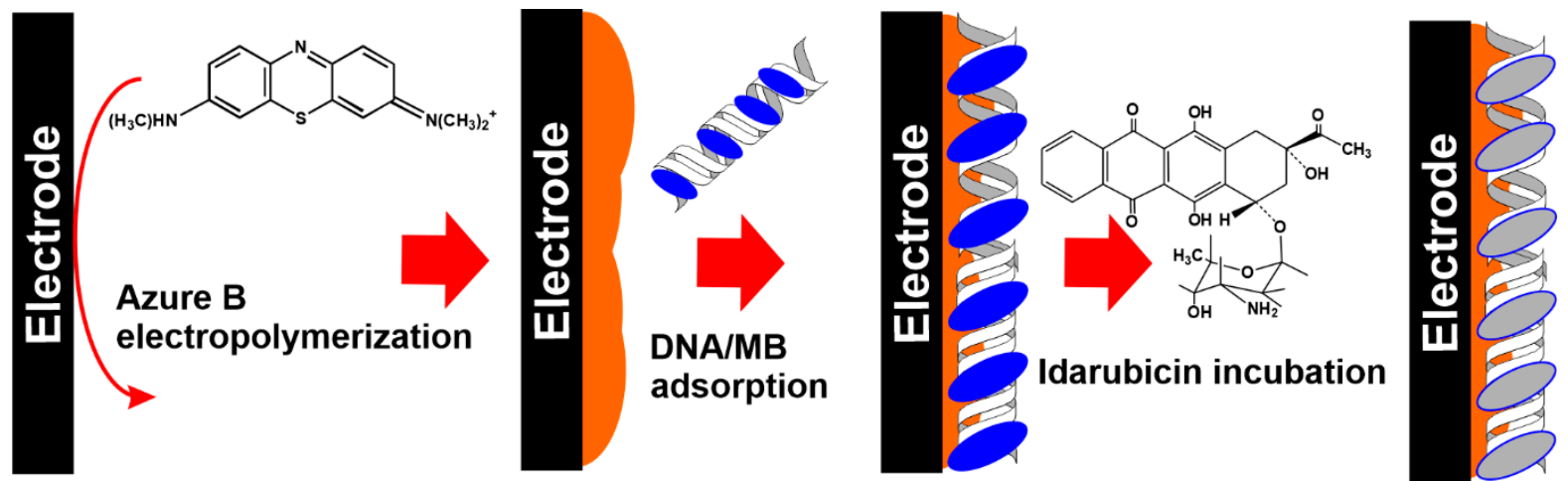

Figure 1. Schematic outline of DNA sensor assembling and idarubicin determination. 
It involves (1) the electropolymerization of Azure B in the buffer saturated with chloroform, improving the performance of the polymer formed; (2) adsorption of DNA saturated with Methylene blue (MB) as an electron transfer mediator; (3) incubation in idarubicin solution. The reaction with DNA releases additional MB molecules participating in the electron exchange and alters the MB reduction signal, measured via cyclic voltammetry.

\section{Materials and Methods}

\subsection{Reagents}

Azure B (dye content 97\%), idarubicin, HEPES (N-(2-hydroxyethyl)piperazine- $\mathrm{N}^{\prime}$-(2ethanesulfonic acid)), DNA from fish sperm, MB and chloroform were purchased from Sigma-Aldrich (Darmstadt, Germany). Other reagents were of analytical grade. Deionized Millipore $\mathrm{Q}^{\circledR}$ water (Molsheim, France) was used for the preparation of working solutions. Electrochemical investigations were performed in 0.1 M HEPES buffer containing $0.03 \mathrm{M}$ $\mathrm{NaCl}, \mathrm{pH}$ 7.0. Electrochemical quartz crystal microbalance (EQCM) measurements were performed in $0.1 \mathrm{M}$ HEPES buffer containing $0.03 \mathrm{M} \mathrm{NaNO}_{3}, \mathrm{pH} 7.0$. The $\mathrm{pH}$ dependence of the sensor signal was monitored using Britton-Robinson buffer, consisting of $0.04 \mathrm{M}$ $\mathrm{H}_{3} \mathrm{PO}_{4}, 0.04 \mathrm{M} \mathrm{H}_{3} \mathrm{BO}_{3}, 0.04 \mathrm{M} \mathrm{CH}_{3} \mathrm{COOH}$, and $0.05 \mathrm{M} \mathrm{Na}_{2} \mathrm{SO}_{4}$. Saturation of the working buffer with chloroform was carried out by mixing in a volume ratio of $4: 1$ and stirring for $30 \mathrm{~min}$. After phase separation, the aqueous phase was taken for the electropolymerization experiments. The idarubicin preparation Zavedos ${ }^{\circledR}$ (Pfizer Inc., New York, NY, USA) was purchased in the local pharmacy market.

\subsection{Apparatus}

Voltammetric and impedimetric measurements were performed at ambient temperature using potentiostat-galvanostat AUTOLAB PGSTAT 302N (Metrohm Autolab b.v., Utrecht, The Netherlands) with FRA2 module. With this, a three-electrode cell provided with a home-made polytetrafluoroethylene-coated glassy carbon working electrode (GCE, $0.0167 \mathrm{~cm}^{2}$ in diameter), $\mathrm{Pt}$ auxiliary electrode and $\mathrm{Ag} / \mathrm{AgCl} / 3 \mathrm{M} \mathrm{KCl}(\mathrm{CH}$ Instruments Inc., Austin, TX, USA) as a reference electrode were used. Cyclic voltammetry (CV) was applied for electrochemical characterization of the poly(azure B) layers that were deposited from the HEPES buffer (PAB-1) and HEPES buffer saturated with chloroform (PAB-2).

The electrochemical impedance spectroscopy (EIS) frequency varied from $100 \mathrm{kHz}$ to $0.04 \mathrm{~Hz}$, the amplitude of the applied sine potential was equal to $5 \mathrm{mV}$, impedance equilibrium potential was calculated as a half-sum of the peak potentials recorded in a $0.01 \mathrm{M}\left[\mathrm{Fe}(\mathrm{CN})_{6}\right]^{3-/ 4-}$ pair as the redox probe. The impedance parameters, such as charge transfer resistance and constant phase element, were calculated from the Nyquist diagram with the $\mathrm{R}(\mathrm{RC})(\mathrm{RC})$ equivalent circuit using NOVA software (Metrohm Autolab b.v., Utrecht, The Netherlands).

Electrochemical quartz crystal microbalance (EQCM) measurements were performed with the EQCM module of the CHI 440B electrochemical analyzer (CH Instruments, Inc. Austin, TX, USA) equipped with the EQCM AT-cut piezo crystal (fundamental frequency $8 \mathrm{MHz}$, diameter of working thin gold electrode: $0.205 \mathrm{~cm}^{2}$ ).

Atomic force microscopy (AFM) images of glassy carbon sheets covered with electropolymerized poly(Azure B) films were obtained by scanning probe microscope Dimension FastScan (Bruker, Bremen, Germany) in the quantitative nanomechanical mapping mode using silicon probes "Bruker scanasyst air" with the radius of curvature $\sim 2 \mathrm{~nm}$ and spring constant $\mathrm{k}=0.4 \mathrm{~N} / \mathrm{m}$. Scan rate was equal to $1 \mathrm{~Hz}$ within $256 \times 256$ window. Image processing was made with the Gwyddion-Free SPM data analysis software.

\subsection{Azure B Electropolymerization and DNA Sensor Preparation}

The GCE electrode was mechanically polished, then cleaned with acetone and deionized water. After that, it was electrochemically treated by repeated multiple potential cycling in $0.1 \mathrm{M} \mathrm{H}_{2} \mathrm{SO}_{4}$. Then, it was immersed in $5 \mathrm{~mL}$ of $0.1 \mathrm{M}$ HEPES buffer containing $0.03 \mathrm{M} \mathrm{NaCl}$, pH 7.0 (in some experiments, saturated with chloroform as mentioned above) 
and $0.5 \mathrm{mM}$ Azure B. The electropolymerization conditions of the Azure B were determined in $[21,22]$ and used as follows. The electrode was polarized at $1.0 \mathrm{~V}$ for $300 \mathrm{~s}$, then the potential of the electrode was cycled 20 times between -0.4 and $1.1 \mathrm{~V}$ with a scan rate of $100 \mathrm{mV} / \mathrm{s}$. Finally, the electrode was thoroughly washed with deionized water and working buffer and air-dried at ambient temperature for $20 \mathrm{~min}$.

The DNA-MB mixture was made with equal volumes of $1 \mathrm{mg} / \mathrm{mL}$ DNA and $5 \mathrm{mM}$ MB solutions. The optimal saturation ratio of DNA with MB was determined prior, in [16]. The electrode with a deposited PAB-1 or PAB-2 layer was fixed upside down and the DNA assembling was performed by drop casting $2 \mu \mathrm{L}$ DNA-MB mixture onto it. The electrode surface was capped with plastic tubing for $10 \mathrm{~min}$ to prevent drying and to control bioreceptor immobilization quantity. Then, the electrode was washed with deionized water, moved to the working buffer solution and 10 cycles of the potential between -0.4 and $0.8 \mathrm{~V}$, $100 \mathrm{mV} / \mathrm{s}$ were used to stabilize the signal by removing unbound dye particles from the polymer layer.

\subsection{Idarubicin Measurements, Real Sample Analysis}

The DNA-MB-modified sensor based on PAB-2 was fixed upside down and $2 \mu \mathrm{L}$ of idarubicin solution in working buffer was placed on the surface. The electrode surface was capped with plastic tubing for 20 min to prevent drying, then washed with deionized water and air-dried at ambient temperature. Then, the electrode was transferred to the electrochemical cell for cyclic voltammetry or impedimetric measurements.

Artificial blood plasma samples were based on Ringer-Locke's solution $(9 \mathrm{~g} / \mathrm{L} \mathrm{NaCl}$, $0.42 \mathrm{~g} / \mathrm{L} \mathrm{KCl}, 0.5 \mathrm{~g} / \mathrm{L} \mathrm{NaH} \mathrm{PO}_{4} \cdot 2 \mathrm{H}_{2} \mathrm{O}, 0.32 \mathrm{~g} / \mathrm{L} \mathrm{CaCl}_{2} \cdot 2 \mathrm{H}_{2} \mathrm{O}, 0.1 \mathrm{~g} / \mathrm{L} \mathrm{NaHCO}, 0.3 \mathrm{~g} / \mathrm{L}$ $\mathrm{MgSO}_{4}, 1.5 \mathrm{~g} / \mathrm{L} \mathrm{D}$-glucose), $\mathrm{pH}$ 7.0. Artificial urine samples contained $20 \mathrm{mM} \mathrm{KCl}, 49 \mathrm{mM}$ $\mathrm{NaCl}, 15 \mathrm{mM} \mathrm{KH}_{2} \mathrm{PO}_{4}, 10 \mathrm{mM} \mathrm{CaCl}_{2}, 18 \mathrm{mM} \mathrm{NH}_{4} \mathrm{Cl}$, and $18 \mathrm{mM}$ urea [22]. The concentration of bovine serum albumin solution was set at $41.4 \mathrm{mg} / \mathrm{mL}$, which corresponds to a moderate level of albumin in adult blood serum.

Human urine samples were collected from healthy volunteers. The $\mathrm{pH}$ value of urine was corrected until it reached 7.0. Sediment that appeared during the $\mathrm{pH}$ correction of the urine sample was gathered using the decantation method.

\section{Results and Discussion}

\subsection{Comparison of Electrochemical Characteristics of PAB-1 and PAB-2 Layers}

The cyclic voltammograms obtained during the electropolymerization process in the presence and absence of chloroform are presented in Figure 2. The multiple cycling of the potential led to the progressive increasing of the peak currents responsive for both monomeric and polymeric forms of the Azure B [23]. The sharp current increase in the high anodic potential area corresponded to the dication radical formation that initiates polymerization [24]. With the cycle number, the increasing anodic currents of monomeric and polymeric forms of Azure B became more evident, whereas cathodic currents merged into one broad peak. Nevertheless, it was obvious that, in the presence of chloroform, the peaks of monomeric and polymeric forms were much better resolved and defined. The influence of chloroform was previously considered for Azure A electropolymerization [21]. As was shown, the polymer deposited in the presence of the solvent contained more pores and showed higher adsorption capabilities than that obtained from aqueous media. This was attributed to the disaggregation of the dye particles on the electrode surface. 


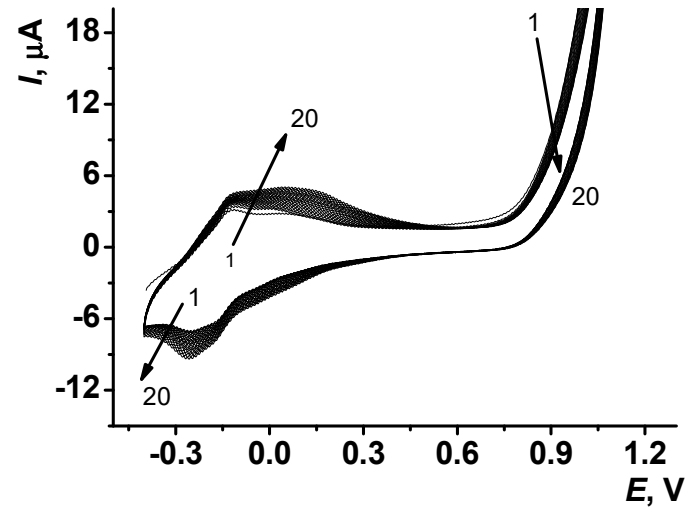

(a)

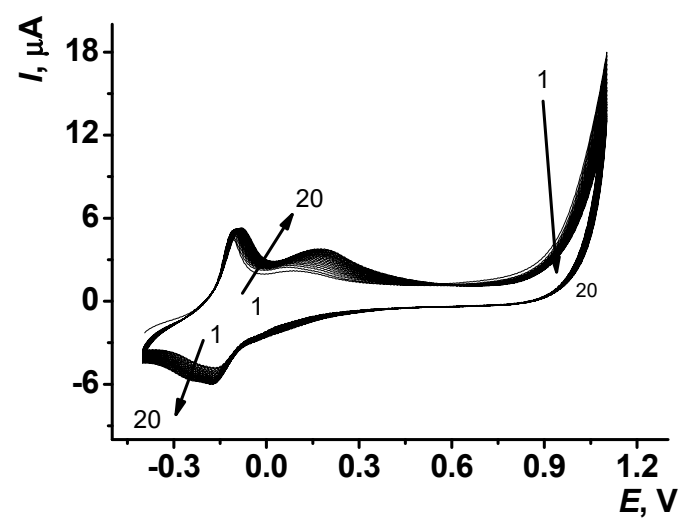

(b)

Figure 2. Cyclic voltammograms recorded on the GCE in $0.1 \mathrm{M}$ HEPES buffer containing $0.03 \mathrm{M}$ $\mathrm{NaCl}, \mathrm{pH}=7.0$, and $0.5 \mathrm{mM}$ Azure B, scan rate $100 \mathrm{mV} / \mathrm{s}$ in the absence (a) and in the presence (b) of chloroform, 20 cycles.

The addition of chloroform to the electropolymerization solution slightly shifts the monomer redox peak potentials to the cathodic direction and the polymer redox peak potentials significantly shift to the anodic area.

After being transferred to the working buffer with no monomer, the GCE modified with PAB-1 and PAB-2 layers demonstrated two pairs of the peaks on the cyclic voltammograms (Figure 3).

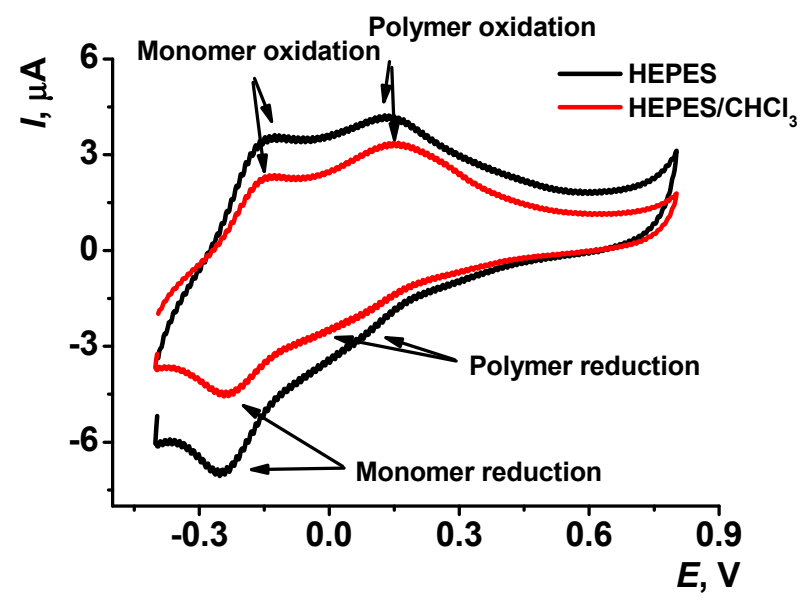

Figure 3. Cyclic voltammogram recorded on the GCE modified with PAB-1 (black) and PAB-2 (red) in $0.1 \mathrm{M}$ HEPES with $0.03 \mathrm{M} \mathrm{NaCl}, \mathrm{pH}=7.0$, scan rate $100 \mathrm{mV} / \mathrm{s}$.

Peak currents in the presence of chloroform are lower compared to those in the water medium. Previously, in the literature, it has been shown that Azure B monomer can be entrapped into the poly(Azure B) film [4]. Poly(Azure B) redox signal stability was tested on six electrodes modified with the same method. After 10 consecutive voltammogram registration, the polymeric form provided a more stable signal compared to the monomeric form. For example, changes in PAB-2 polymer reduction signal were about $1 \%$, whereas monomer reduction signal reduced twice. This could be explained by leaching of the monomer from the surface layer. The magnitude and ratio between two described pairs of redox peaks for PAB-1 and PAB-2 was strictly influenced by the $\mathrm{pH}$ value (Figure 4). 


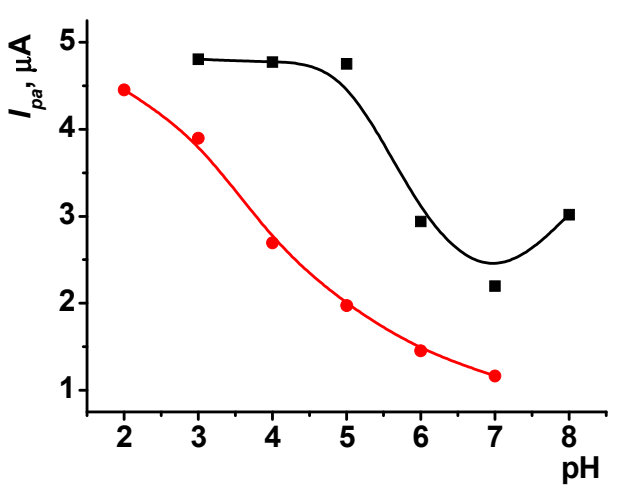

(a)

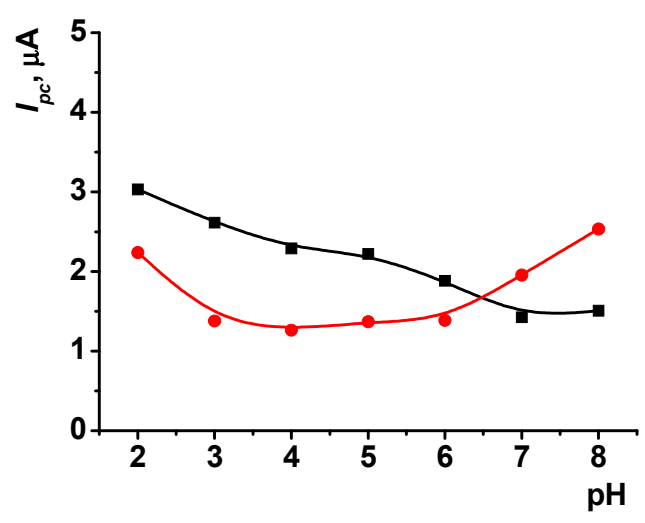

(c)

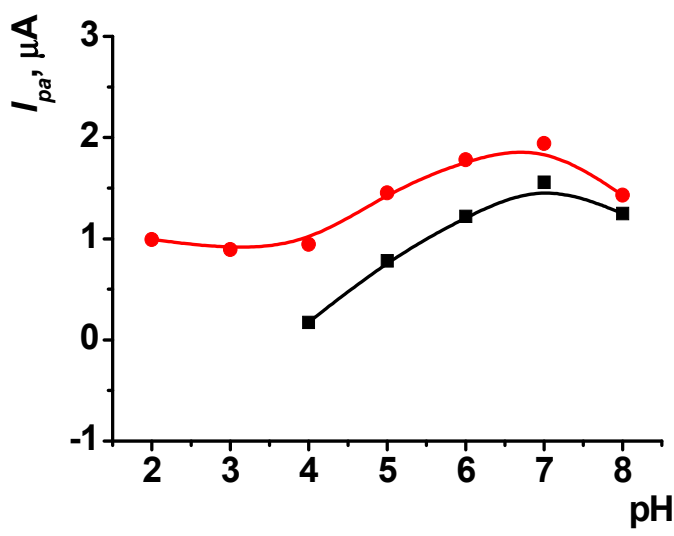

(b)

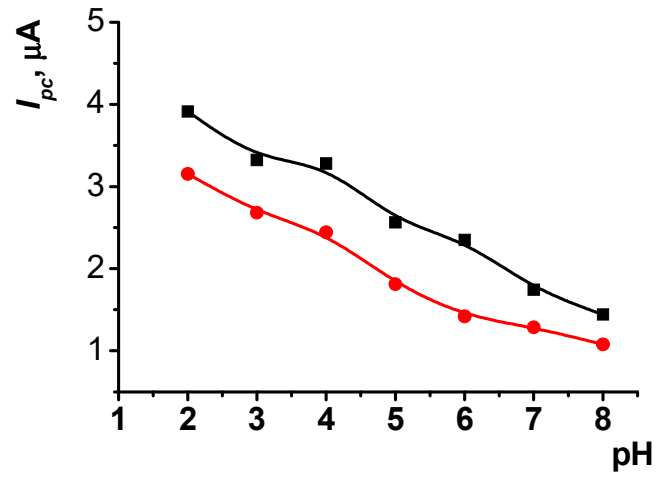

(d)

Figure 4. The $\mathrm{pH}$ dependence of the anodic peak current of the monomer (a) and polymer (b), cathodic peak current of the monomer (c) and polymer (d) for PAB-1 (black) and PAB-2 (red) layers, Britton-Robinson buffer, $\mathrm{pH}$ 2-8.

Generally, the addition of chloroform to the electropolymerization medium expanded the working area of the modified GCE. Apart from the polymer oxidation peak, all other redox peaks for PAB-2 were smaller than for PAB-1 and the corresponding current dependences on $\mathrm{pH}$ were shifted to more acidic media. The oxidation peak current of the PAB-1 monomeric form was stable in acidic and weakly acidic media, then decreased to a minimum in the neutral media. The oxidation peak current of the PAB-2 monomeric form monotonically decreased throughout the $\mathrm{pH}$ range from 2 to 7 . The oxidation peak current of the polymeric form PAB-1 was well defined only in the $\mathrm{pH}$ range from 4 to 8 , whereas the oxidation peak current of the PAB-2 occurred in all studied $\mathrm{pH}$ ranges. Both PAB-1 and $\mathrm{PAB}-2$ demonstrated the maximum at $\mathrm{pH}=7$. Reduction peak currents of the PAB-2 monomeric form were quite stable in the $\mathrm{pH}$ range between 3 and 6 and increased when transferred to the more acidic or alkaline solutions. Small-scale decay was observed on PAB-1 reduction peak current dependence on $\mathrm{pH}$. Reduction peak currents of the PAB-1 and PAB-2 polymeric form steadily decreased in all studied $\mathrm{pH}$ ranges. The half-sum of peak potentials for monomeric and polymeric forms of poly(Azure B) was used as formal redox potential. In the case of the monomeric form there were no significant differences between PAB-1 and PAB-2 slopes of the $\mathrm{pH}$ dependences of the formal redox potential; the appropriate slopes were close to theoretical Nernst slope of $59 \mathrm{mV} / \mathrm{pH}$ that corresponds to the transfer of equal electrons and $\mathrm{H}^{+}$numbers. However, it should be mentioned that for $\mathrm{PAB}-2$, the $\mathrm{pH}$ dependence linearity range was almost twice as wide, from 2 to 7 as compared to from 4 to 8 for PAB-1. Meanwhile, the slopes for the PAB-1 and PAB-2 polymeric form were significantly different. The polymeric form derived from the aqueous 
medium showed a slope of $35 \mathrm{mV} / \mathrm{pH}$ in the $\mathrm{pH}$ range from 4 to 8 , corresponding to two electrons and one $\mathrm{H}^{+}$transfer. The polymeric form derived from the aqueous-organic medium demonstrated a slope of $43 \mathrm{mV} / \mathrm{pH}$ that formally corresponds to 1.5 electrons and one $\mathrm{H}^{+}$transfer. It could be associated with the better intrinsic buffer properties of PAB-2 polymer or with the higher sensitivity of the PAB-2 layer to additional chemical reactions between dissolved oxygen and the polymer layer. The $\mathrm{pH}$ dependence of the peak currents confirmed the possibility of monitoring the redox signals in the neutral and weak acidic media most compatible with biochemical interactions involving DNA.

According to the slope of bilogarithmic dependence of the peak current $\left(I_{p}\right)$ on the scan rate $(v)$ for PAB-2, the limiting step of the monomeric form redox conversion and polymeric form reduction was diffusion $\left(\mathrm{d}\left(\log \mathrm{I}_{\mathrm{p}}\right) / \mathrm{d}(\log v)=0.58 \pm 0.04\right.$ and $0.61 \pm 0.01$ for monomer oxidation and reduction, respectively, and $0.61 \pm 0.01$ for polymer reduction). Oxidation of the polymeric form for PAB-2 demonstrated a slope of $1.00 \pm 0.01$, concerning the adsorption control of the polymer conversion. Nevertheless, monomeric form redox conversion for PAB-1 showed mixed adsorption-diffusion control $\left(\mathrm{d}\left(\log \mathrm{I}_{\mathrm{p}}\right) / \mathrm{d}(\log v)=0.76 \pm 0.03\right.$ and $0.83 \pm 0.01$ for monomer oxidation and reduction, respectively), whereas polymeric form redox conversion was controlled by adsorption $\left(\mathrm{d}\left(\log \mathrm{I}_{\mathrm{p}}\right) / \mathrm{d}(\log v)=1.13 \pm 0.02\right.$ and $0.89 \pm 0.02$ for polymer oxidation and reduction, respectively).

\subsection{EQCM Measurements}

The effect of the addition of chloroform on Azure B electropolymerization efficiency was studied via EQCM measurements (fundamental frequency: $8 \mathrm{MHz}$, area of the electrode: $0.205 \mathrm{~cm}^{2}$ ). The frequency shift of the quartz oscillation depends on substance mass change deposited onto the electrode surface in accordance with the Sauerbrey Equation (2).

$$
\Delta f=-\frac{2 f_{0}^{2} \Delta m}{A \sqrt{\rho_{q} \mu_{q}}}=-C_{f} \Delta m
$$

Here, $\Delta f$ is a frequency shift, $\mathrm{A}$ the area of Au electrode, $\rho_{q}$ the quartz density, $\mu_{q}$ the shear modulus, $f_{0}$ the fundamental frequency of the crystal, $\mathrm{C}_{f}$ the sensitivity coefficient and $\Delta m$ the surface mass change. Equation (2) is valid only for dry films deposited onto the crystal surface. In the case of rigid films in aqueous solution, this equation can be also used considering a correction factor of approximately 2 as well as changes of frequency due to viscoelasticity [25].

Simultaneous voltammogram and sensogram detection during the Azure B electropolymerization process demonstrated the notable influence of buffer saturation with chloroform. In Figure 5, sensograms and cyclic voltammograms are presented for the first (Figure $5 a, c$ ) and tenth (Figure $5 b, d$ ) cycles of the potential scanning. The A zone corresponds to the area of monomer $(\mathrm{M})$ and polymer $(\mathrm{P})$ electrochemical activity. The most characteristic changes in voltammograms and sensograms appear in this zone. The $B$ zone belongs to the high anodic potential area, where dication radical formation occurs. The electropolymerization process included two stages: polarization at $1 \mathrm{~V}$ and multiple potential cycling. It can explain the appearance of voltammetric signals of $\mathrm{M}^{\mathrm{a}}$ and $\mathrm{P}^{\mathrm{a}}$ in $\mathrm{A}$ area even at 1 scan (Figure $5 \mathrm{a}, \mathrm{c}$ ). The accumulation of electropolymerization products led to an increase in currents and the merging of $\mathrm{M}^{\mathrm{a}}$ and $\mathrm{P}^{\mathrm{a}}\left(\mathrm{M}^{\mathrm{c}}\right.$ and $\left.\mathrm{P}^{\mathrm{c}}\right)$ into one broad peak $\mathrm{M}^{\mathrm{a}}+\mathrm{P}^{\mathrm{a}}\left(\mathrm{M}^{\mathrm{c}}+\mathrm{P}^{\mathrm{c}}\right)$, both for aqueous and aqueous-organic media (Figure $5 \mathrm{~b}, \mathrm{~d}$ ). 


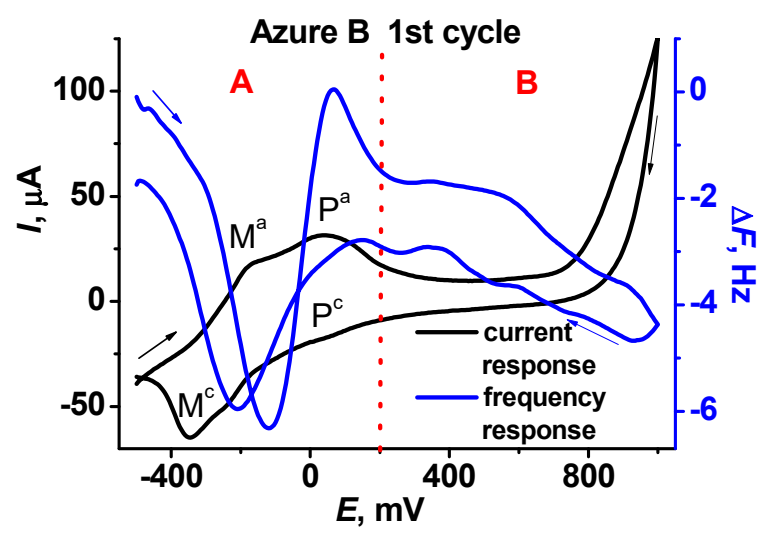

(a)

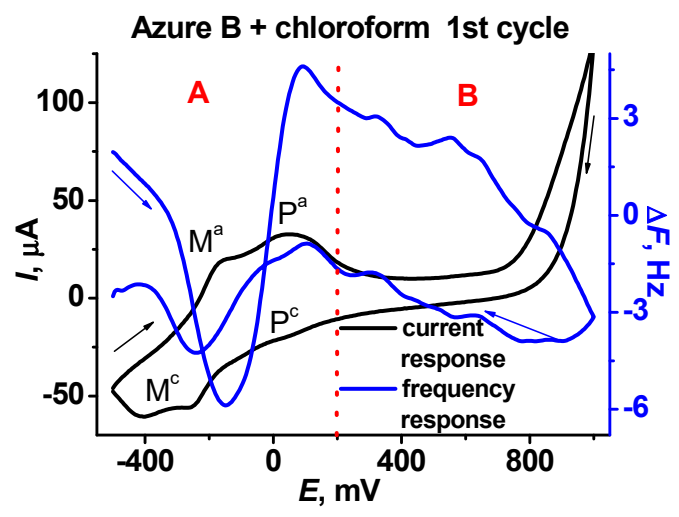

(c)

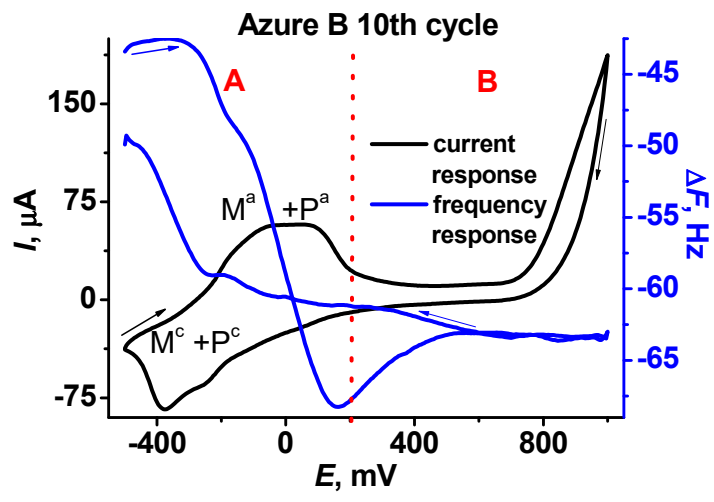

(b)

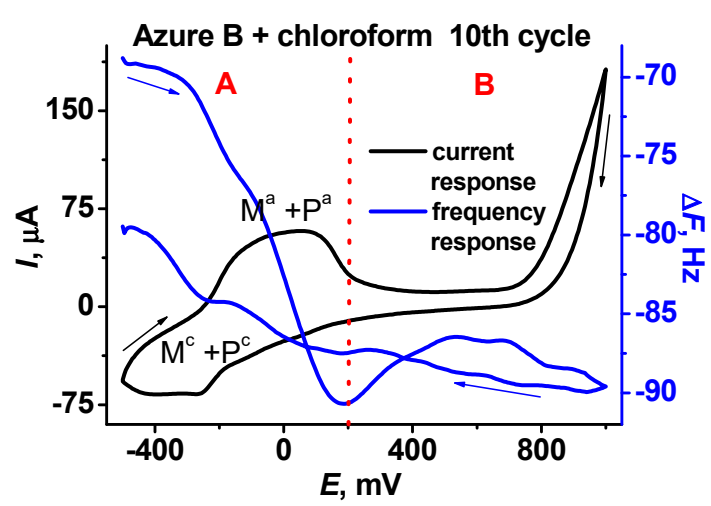

(d)

Figure 5. Cyclic voltammograms (black) and sensograms (blue) recorded on QCM chip in $0.1 \mathrm{M}$ HEPES buffer containing $0.03 \mathrm{M} \mathrm{NaNO}_{3}, \mathrm{pH}=7.0(\mathbf{a}, \mathbf{b})$ and saturated with chloroform (c,d), in the presence of $0.5 \mathrm{mM}$ Azure B. Arrows indicate the direction of the potential scan.

Sonograms changed radically from the first to the tenth scan. In the first scan, monomer oxidation $\mathrm{M}^{\mathrm{a}}$ (Figure $5 \mathrm{a}$ ) was accompanied by a frequency decrease, due to adsorption of Azure B in its oxidized form. The polymer oxidation signal $\mathrm{P}^{\mathrm{a}}$ was accompanied by an acute rise in frequency response, which corresponds to the decrease in deposited mass. Polymer redox conversion caused the changes in its charge and was supported by the counterion doping/dedoping process. Unfortunately, it is not possible to explain this mass decay by means of the polymer dedoping process since the most expected process through the oxidation of polymers is the doping process, which involves anion inclusion into the polymer matrix. Most probably, in the first scan, the Au surface is not fully covered and electrostatic interaction between charged monomer molecules and the surface takes place at the same time as zero-charge potential crossing. Thus, V-shaped frequency changes were observed; an initial decrease owing to adsorption of positively charged monomer molecules and their further desorption after zero-charge potential crossing. On the reverse branch, sorption occurs at more positive potentials that can be explained by the zero-charge potential shift of the surface after its modification with additional polymers in the B zone. The contribution of the doping process increased when moving to the thicker layers. The polymer oxidation was supported with frequency oscillation decay. Desorption began at more positive potentials and appeared in the A and B zones (Figure 5b,d).

Chloroform addition did not provoke any significant morphological changes in the voltammograms or sensograms. However, greater intensity of material accumulation on the electrode surface in the aqueous-organic medium should be noticed. The currents and frequency changes, $\Delta \mathrm{F}$, increased compared to the water media (Figure 6). Quartz crystal frequency linearly depended on the cycle number in voltammetric measurements. 
The effect of buffer saturation with chloroform became more significant with greater cycle numbers.

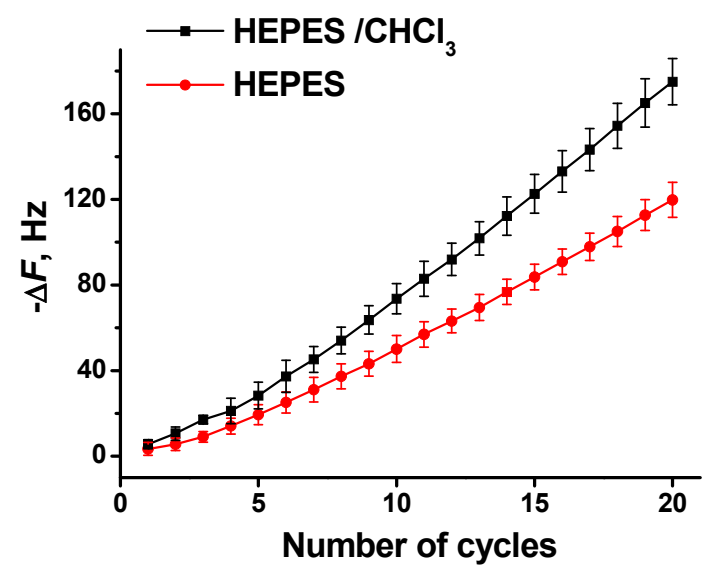

Figure 6. Dependence of the EQCM frequency shift on the number of potential cycles during poly(Azure B) electropolymerization in different conditions. Results represent mean \pm S.D. obtained from 6 independent experiments.

The EQCM results were well-reproducible and deviation of the frequency shift for six independent measurements with different EQCM chips did not exceed 6.8\%.

\subsection{Atomic Force Microscopy Measurements of PAB-1 and PAB-2 Layers}

Morphological characterizations of the polymer PAB-1 and PAB-2 layers were obtained by AFM measurement with the scanning probe microscope Dimension FastScan (Bruker, Bremen, Germany). In the HEPES buffer solution, poly(Azure B) formed a granulated rough surface with some rounded structures on it. The saturation of electropolymerization media with chloroform leads to more uniform and even layer formation (Figure 7). Total roughness and height deviation were decreased.

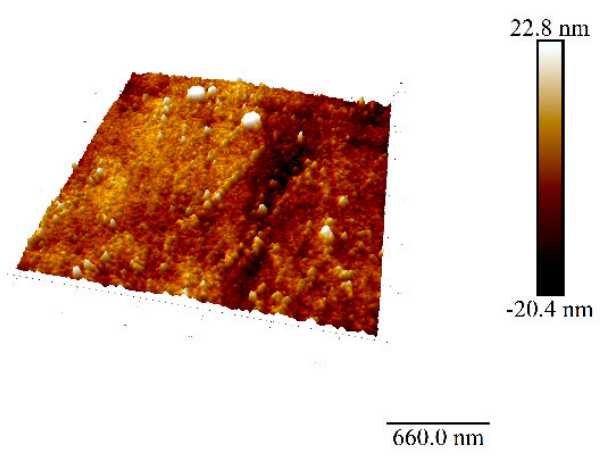

(a)

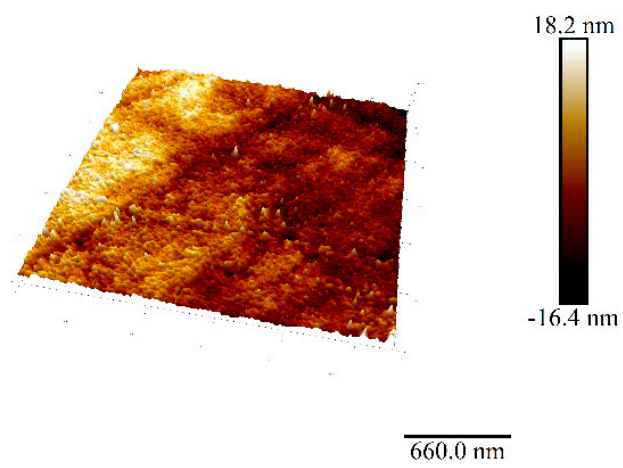

(b)

Figure 7. 3D AFM topography of the films on the GCE surface covered with Azure B electropolymerized from 0.1 M HEPES buffer containing $0.03 \mathrm{M} \mathrm{NaCl}$, pH $7.0(\mathbf{a})$ in the presence of $\mathrm{CHCl}_{3}(\mathbf{b})$ after 20 cycles of electropolymerization.

\subsection{Idarubicin Determination by Voltammetry}

The anthracycline antibiotic idarubicin interacts with the DNA helix via intercalation between base pairs [26]. If double-stranded DNA was immobilized on the PAB-2 surface by physical adsorption from $2 \mu \mathrm{L}$ drop of $1 \mathrm{mg} / \mathrm{mL}$ DNA solution for $10 \mathrm{~min}$, peak currents for redox conversion of the monomeric form were significantly decreased, whereas peak 
currents of the Azure B polymeric form changed slightly. Interaction of the idarubicin solution with GCE/PAB-2/DNA additionally decreased the redox signal of the PAB-2 monomeric form, but overall changes were too small to make any quantitative assessments.

The incorporation of MB into the biorecognizing layer of DNA increased the sensitivity of idarubicin determination. $\mathrm{MB}$ core is a planar phenothiazine derivative that can interact with DNA via intercalation or groove modes [27]. The concentration ratio between MB and fish sperm DNA was estimated from the maximum feasible MB binding. The latter was calculated from the saturation curve inflection point. Implementation of the DNA/MB increased the PAB peak currents. Meanwhile, no peaks of the dye appeared. This made it possible to conclude that the MB molecules are involved in the electron transfer chain, but are not in physical contact with the electrode surface. Incubation in buffer removes dye molecules adsorbed on the minor grooves of the DNA helix, so that the PAB peak currents became lower. Idarubicin compensates for the losses of MB molecules available for the mediation of electron transfer due to displacement of the MB intercalated with the DNA helix. Similar behavior can be expected from other intercalators able to compete with MB for the DNA binding sites, e.g., anthracycline cytostatics (doxorubicin, daunorubicin). Figure 8 shows cyclic voltammograms recorded with $1 \times 10^{-15} \mathrm{M}-1 \times 10^{-7} \mathrm{M}$ idarubicin solution ( $2 \mu \mathrm{L}$ aliquot, incubation $20 \mathrm{~min}$.). Relative changes in cathodic current were more sensitive to idarubicin concentration, so it was chosen as the analytical signal. Such behavior differs from that commonly observed for the MB-based detection of DNA sensor signals. This is due to two peculiarities of the measurement protocol: (1) MB is not present in the buffer but added with DNA to the surface layer; (2) MB/DNA ratio corresponds to maximal binding of the dye with the biopolymer.

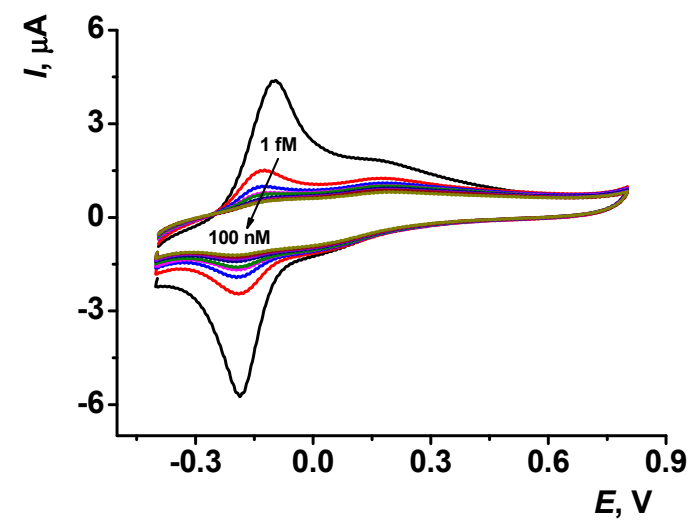

Figure 8. Cyclic voltammograms recorded on the GCE covered with the PAB-2/DNA-MB film prior to and after $20 \mathrm{~min}$ incubation in $1 \mathrm{fM}, 10 \mathrm{fM}, 100 \mathrm{fM}, 1 \mathrm{pM}, 10 \mathrm{pM}, 100 \mathrm{pM}, 1 \mathrm{nM}, 10 \mathrm{nM}, 100 \mathrm{nM}$ idarubicin solution, $0.1 \mathrm{M}$ HEPES buffer containing $0.03 \mathrm{M} \mathrm{NaCl}, \mathrm{pH} 7.0$.

Thus, idarubicin influenced the DNA-MB system and changed the quantities of MB available for electron transfer mediation. The calibration curve for idarubicin determination was plotted in semi-logarithmic coordinates (Figure 9). The analytical signal was calculated as the difference between analyte determination and blank experiment signals. The LOD value was evaluated as $\mathrm{S} / \mathrm{N}=3$ criterion. We have not found any drift of the signal when the period between the biosensor assembly and idarubicin addition varied from several hours to 3 days. 


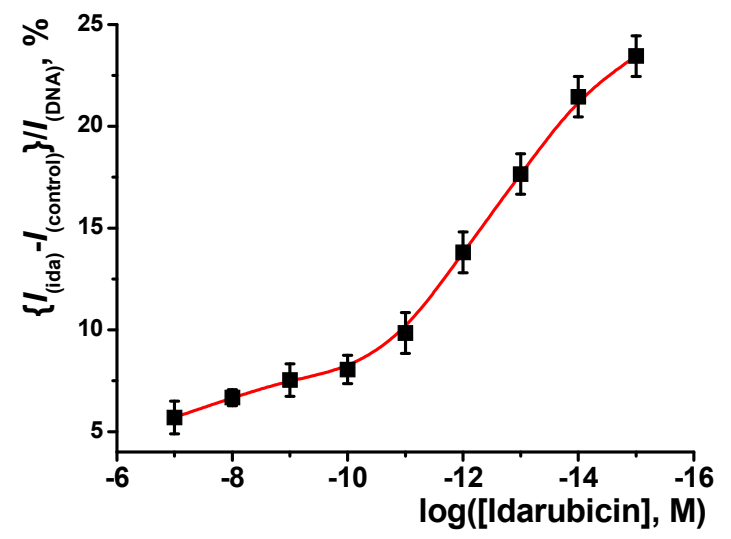

Figure 9. Calibration curve for idarubicin determination on PAB-2/DNA-MB. Cyclic voltammetry, 0.1 M HEPES buffer containing 0.03 M NaCl, pH 7.0.

The appropriate calibration curve was linear within the idarubicin concentration range from $1 \mathrm{fM}$ to $0.1 \mathrm{nM}$ (Equation (3)).

$$
\left.\left(\mathrm{I}_{(\mathrm{ida})}-\mathrm{I}_{(\mathrm{control})}\right) / \mathrm{I}_{(\mathrm{DNA})}\right), \%=(-26 \pm 2)+(-3.0 \pm 0.2) \times \log [\text { Idarubicin }], \mathrm{M} ; R^{2}=0.985
$$

The proposed PAB-2/DNA-MB biosensor LOD was found to be $0.3 \mathrm{fM}$. All the experimental points have been obtained using at least six individual PAB-2/DNA-MB sensors manufactured as described above.

\subsection{Real Sample Voltammetric Analysis}

The applicability of the PAB-2/DNA-MB biosensor for biological fluids analysis was confirmed by experiments with Ringer-Locke's solution, bovine serum albumin solution, artificial urine and human urine spiked with 1pM of idarubicin (Table 1).

Table 1. Determination of $1 \mathrm{pM}$ idarubicin in spiked samples of various media mimicking serum, blood plasma, in artificial and human urine by cyclic voltammetry method. Mean \pm S.D. for six individual sensors.

\begin{tabular}{ccc}
\hline Media & $\left.\left.\mathbf{( I}_{(\mathbf{i d a})}-\mathbf{I}_{(\text {control })}\right) / \mathbf{I}_{(\text {DNA })}\right), \%$ & Recovery, $\%$ \\
\hline Ringer-Locke's solution & $22.0 \pm 2.3$ & $110 \pm 12$ \\
BSA solution & $21.0 \pm 1.3$ & $103 \pm 7$ \\
Artificial urine & $21.0 \pm 2.1$ & $104 \pm 10$ \\
Human urine, & $22.0 \pm 1.5$ & $110 \pm 8$ \\
dilution 1:1 & & \\
\hline
\end{tabular}

As for idarubicin detection in artificial biological liquids, no significant influence on the current change in the presence of idarubicin was found. Ringer-Locke's solution, mimicking blood plasma, slightly increased the signal of the biosensor. Bovine serum albumin solution, mimicking human serum, and artificial urine did not alter the signal of the biosensor. Measurement in non-diluted urine gave the understated results probably due to adsorption on the suspended solid microparticles such as cells, casts, protein cylinders, crystals or amorphous sediments of chemical substances [28]. To prevent this effect of human urine, it should be diluted with working buffer in a 1:1 volume ratio.

The DNA biosensor was also used for idarubicin commercial medication Zavedos ${ }^{\circledR}$. It was first dissolved in the deionized Millipore $\mathrm{Q}^{\circledR}$ water to $0.01 \mathrm{M}$ (stock solution) and then diluted with working buffer. Zavedos ${ }^{\circledR}$ powder for preparation of solution for injection contains $5 \mathrm{mg}$ idarubicin hydrochloride and $50 \mathrm{mg}$ of lactose monohydrate in each vial. It was found that lactose used for idarubicin stabilization in medication strongly affected the redox equilibrium of $\mathrm{MB}$ and critically reduced the sensitivity of idarubicin detection 
(Figure 10). This might be due to antioxidant properties of lactose that influence the electron exchange reactions on the electrode interface.

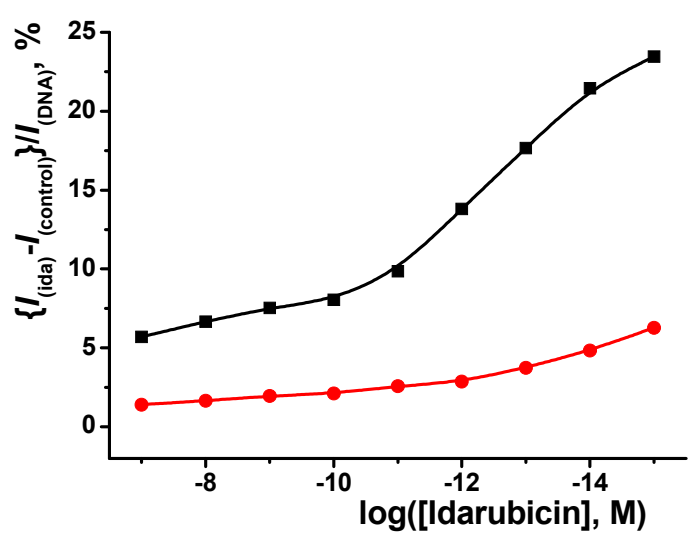

Figure 10. Comparison of idarubicin calibration curves in standard solutions (black) and in commercial medication Zavedos ${ }^{\circledR}$ (red) on PAB-2/DNA-MB, cyclic voltammetry, 0.1 M HEPES buffer containing $0.03 \mathrm{M} \mathrm{NaCl}$, pH 7.0.

\subsection{Idarubicin Impedimetric Measurements}

Idarubicin determination was also performed in the EIS mode, which is often more sensitive to electrode surface reactions followed by interface charge and capacity changes. EIS measurements were carried out in an equimolar mixture of $0.01 \mathrm{M}\left[\mathrm{Fe}(\mathrm{CN})_{6}\right]^{3-}$ and $\left[\mathrm{Fe}(\mathrm{CN})_{6}\right]^{4-}$ ions as a redox probe. The impedance equilibrium potential for all investigated samples was $0.247 \mathrm{~V}$. An equivalent scheme $R\left(R_{1} C_{1}\right)\left(R_{2} C_{2}\right)$ was used for the experimental result interpretation (4). $R_{1}$ and $C_{1}$ were attributed to the processes on the inner interface (electrode-modificator layer), while $\mathrm{R}_{2}$ and $\mathrm{C}_{2}$ are related to the outer interface (modificator layer-solution). Charge transfer resistance and constant phase element $\mathrm{CPE}$ were chosen as EIS characteristic parameters.

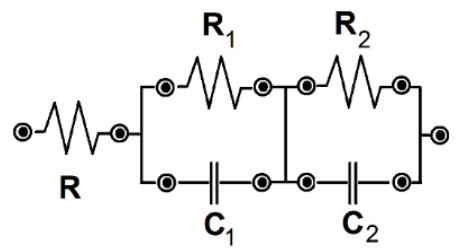

The DNA helix bears negative charge and is nonconductive. Therefore, DNA implementation into the PAB-2 surface layer results in an increase in charge transfer resistance. Idarubicin intercalates the DNA helix and incorporates between pairs of nucleobases. Intercalation increases the charge separation and changes the volume of the DNA molecule which results in the subsequent increase in the charge transfer resistance. Reaction with idarubicin did not affect the $R_{1}$ and $C_{1}$ parameters of the inner interface. The constant phase element of the outer interface $C_{2}$ was also not sensitive to the compound of the biosensor recognizing layer (Figure $11 \mathrm{~b}$ ). In contrast the sensitivity of $\mathrm{R}_{2}$ parameter toward the idarubicin concentration was much better than that of voltammetric measurements (Figure 11a). 


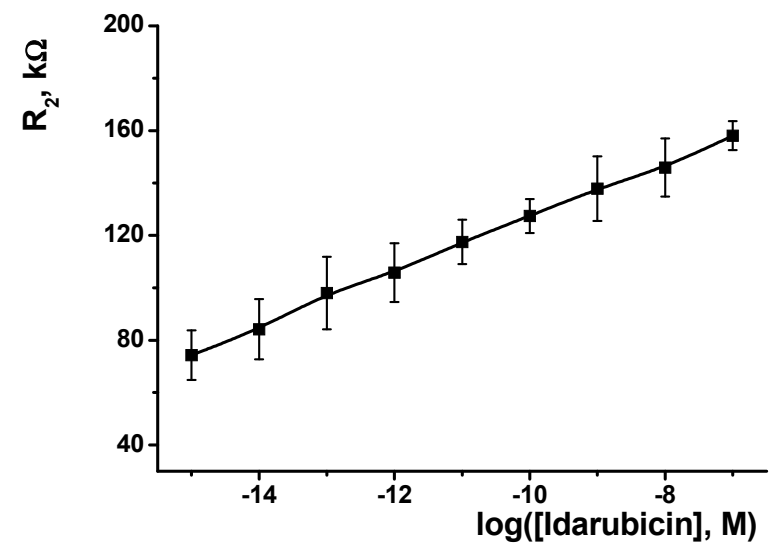

(a)

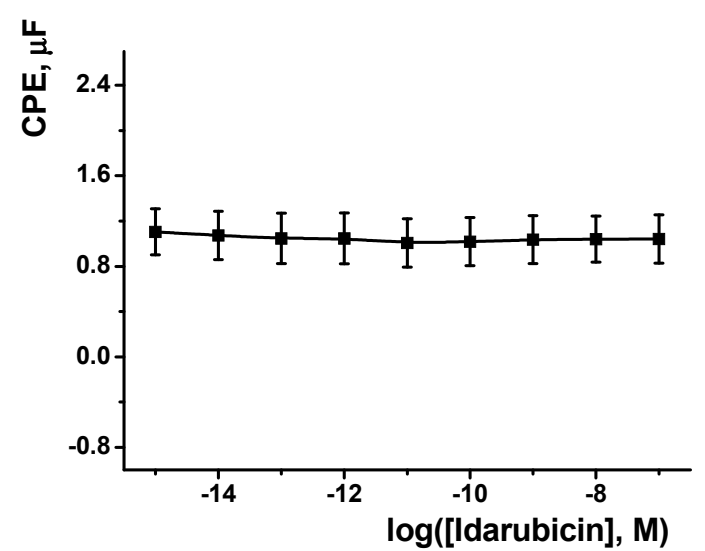

(b)

Figure 11. (a) Charge transfer resistance, and (b) constant phase element dependence on idarubicin concentration in PAB-2/DNA-MB, EIS, 0.1 M HEPES buffer containing $0.03 \mathrm{M} \mathrm{NaCl}$, pH 7.0 in the presence of an equimolar mixture of $0.01 \mathrm{M}\left[\mathrm{Fe}(\mathrm{CN})_{6}\right]^{3-}$ and $\left[\mathrm{Fe}(\mathrm{CN})_{6}\right]^{4-}$ ions. Results are mean \pm S.D. obtained from 6 independent experiments.

Six PAB-2/DNA-MB sensors were used to assess the signal reproducibility. The linear range of concentrations was from $1 \mathrm{fM}$ to $100 \mathrm{nM}$ of idarubicin with LOD $0.3 \mathrm{fM}$, so it was extended for three orders of magnitude compared to voltammetry (Equation (5)). The LOD value was evaluated as $\mathrm{S} / \mathrm{N}=3$ criterion.

$$
R_{2}, \mathrm{k} \Omega=(231 \pm 2)+(10.4 \pm 0.2) \log (C, \mathrm{M}), R^{2}=0.9980, \mathrm{n}=6
$$

\subsection{Real Sample Impedimetric Analysis}

Real and artificial spiked sample analysis by impedance spectroscopy yielded satisfactory results towards idarubicin determination in bovine serum solution and in artificial urine (Table 2). Ringer-Locke's solution tended to understate the results obtained. Urine samples from conditionally healthy volunteers had to be diluted twice with working buffer before measurements in order to prevent the interfering influence of the matrix.

Table 2. Determination of $1 \mathrm{pM}$ idarubicin in spiked samples of various media mimicking serum, blood plasma, in artificial and human urine by electrochemical impedance spectroscopy. Mean \pm S.D. for six individual sensors.

\begin{tabular}{ccc}
\hline Media & $\boldsymbol{R}_{\mathbf{2}}, \mathbf{k} \boldsymbol{\Omega}$ & Recovery, $\%$ \\
\hline Ringer-Locke's solution & $73.2 \pm 11.1$ & $69 \pm 11$ \\
BSA solution & $97.2 \pm 20.6$ & $92 \pm 19$ \\
Artificial urine & $97.1 \pm 16.8$ & $92 \pm 16$ \\
Human urine, & $102.9 \pm 11.3$ & $97 \pm 11$ \\
dilution 1:1 & & \\
\hline
\end{tabular}

Zavedos ${ }^{\circledR}$ medical preparation was also tested in EIS mode. Lactose presence in the medical preparation sample led to a shift of the concentration dependence to the lower values of $R_{2}$, with the slope being retained. To confirm the lactose influence, an artificial mixture with a corresponding content of lactose monohydrate and idarubicin was prepared (Figure 12a). The lactose concentration corresponded to its content in the Zavedos ${ }^{\circledR}$. Constant phase element did not change throughout the concentration range (Figure 12b). Equations for the corresponding concentration dependences are listed below Equations (6) and (7):

$$
R_{2}, \mathrm{k} \Omega=(176 \pm 3)+(8.1 \pm 0.3) \times \log \left[\text { Zavedos }^{\circledR}\right], \mathrm{M} ; R^{2}=0.9911
$$




$$
R_{2}, \mathrm{k} \Omega=(146 \pm 4)+(6.0 \pm 0.3) \times \log [\text { Idarubicin }+ \text { lactose }], \mathrm{M} ; R^{2}=0.9783
$$

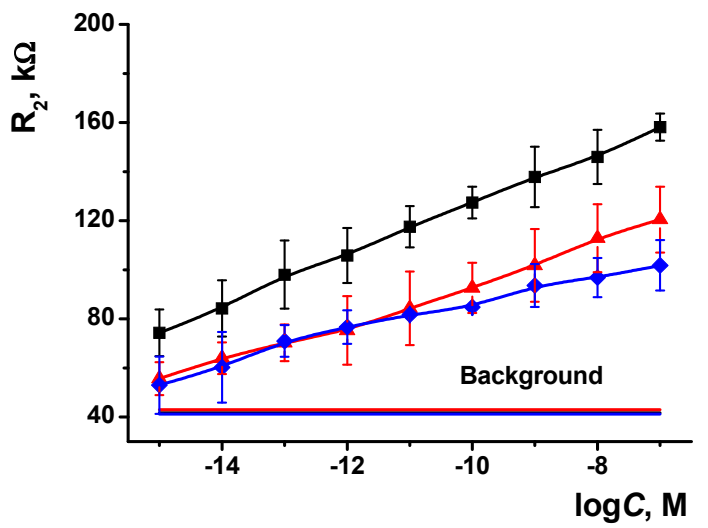

(a)

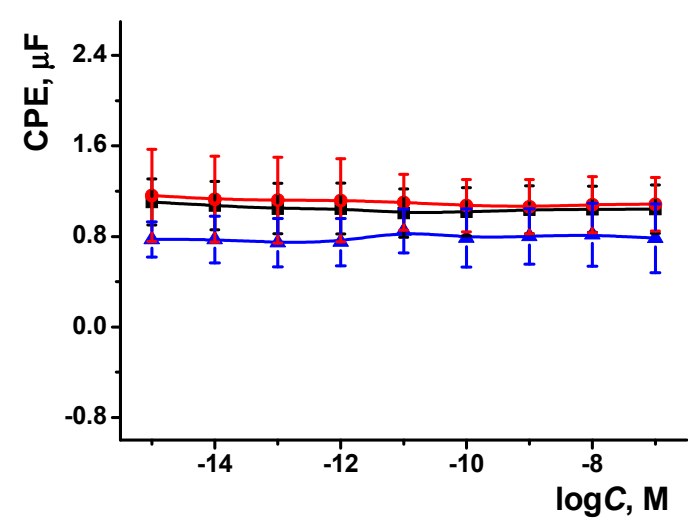

(b)

Figure 12. (a) Charge transfer resistance, and (b) constant phase element dependence on idarubicin concentration in standard solution (black), in Zavedos ${ }^{\circledR}$ medical preparation (red), in artificial mixture of idarubicin standard solution and lactose monohydrate (blue) on PAB-2/DNA-MB, EIS, $0.1 \mathrm{M}$ HEPES buffer containing $0.03 \mathrm{M} \mathrm{NaCl}$, pH 7.0 in presence of equimolar mixture of $0.01 \mathrm{M}\left[\mathrm{Fe}(\mathrm{CN})_{6}\right]^{3-}$ and $\left[\mathrm{Fe}(\mathrm{CN})_{6}\right]^{4-}$ ions. Results are mean \pm S.D. obtained in 6 independent experiments.

Typical Nyquist diagrams obtained after the incubation of the biosensor in idarubicin standard solution (black), Zavedos ${ }^{\circledR}$ medical preparation (red), and an artificial mixture of idarubicin standard solution and lactose monohydrate (blue) are presented in Figure 13.

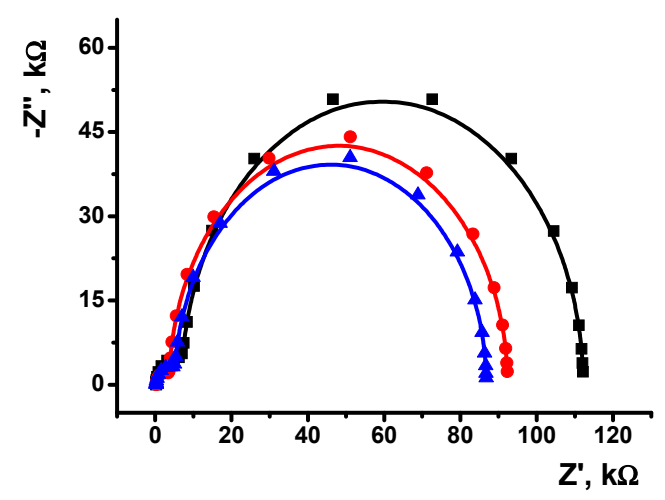

Figure 13. Nyquist diagrams obtained for idarubicin determination in standard solution (black), Zavedos ${ }^{\circledR}$ medical preparation (red), artificial mixture of idarubicin standard solution and lactose monohydrate (blue) on PAB-2/DNA-MB, EIS, 0.1 M HEPES buffer containing $0.03 \mathrm{M} \mathrm{NaCl}$, pH 7.0 in the presence of equimolar mixture of $0.01 \mathrm{M}\left[\mathrm{Fe}(\mathrm{CN})_{6}\right]^{3-}$ and $\left[\mathrm{Fe}(\mathrm{CN})_{6}\right]^{4-}$ ions.

\section{Conclusions}

In this work, the polymeric form of Azure B obtained from a working buffer saturated with chloroform has been, for the first time, applied for the voltammetric and impedimetric determination of idarubicin, a cytostatic anthracycline chemotherapy drug used for acute myelogenous leukemia and the chemotherapy of other cancer diseases. The developed biosensor was sensitive towards idarubicin at physiological $\mathrm{pH}$ values. AFM, EQCM and EIS methods were used to prove the assembling of the surface layer and assess the influence of the presence of organic solvents in the electropolymerization media. The incorporation of $\mathrm{MB}$ into the biorecognizing layer increased the sensor's sensitivity. The incubation of PAB-2/DNA + MB in idarubicin solution resulted in displacement of MB in the DNA helix. The concentration range for idarubicin determination by cyclic voltammetry was from $1 \mathrm{fM}$ to $0.1 \mathrm{nM}$, with an LOD of $0.3 \mathrm{fM}$. Using EIS instead of $\mathrm{CV}$ widened the linear 
range of idarubicin concentration from $1 \mathrm{fM}$ to $100 \mathrm{nM}$, retaining an LOD of $0.3 \mathrm{fM}$. The PAB-2/DNA + MB biosensor was tested in real and artificial solutions of biological fluids to evaluate the possibility of idarubicin detection in complex matrices. It has been shown that there is no strong interfering action from fluid components and twice-diluted human urine samples in the detection of idarubicin. The poly(Azure B)-based DNA biosensor was also successfully used for impedimetric idarubicin detection in medical preparation Zavedos $^{\circledR}$. Thus, the developed DNA biosensor can find applications in medical therapy control, pharmacokinetics investigations, drug content control, and in medications.

Author Contributions: Investigation, A.G., Y.K. and V.E.; validation A.G. and Y.K., formal analysis Y.K., A.P., V.E. and G.E.; conceptualization, G.E.; methodology, G.E.; writing-original draft preparation, A.P. and G.E., writing-review and editing, G.E. and T.H.; supervision, G.E.; project administration, T.H.; funding acquisition, A.P. and T.H. All authors have read and agreed to the published version of the manuscript.

Funding: A.P. announces the financial support of Russian Science Foundation (grant 17-73-20024). T.H. is grateful to Science Agency VEGA, project No. 1/0419/20, for financial support.

Institutional Review Board Statement: Not applicable.

Informed Consent Statement: Not applicable.

Data Availability Statement: Not applicable.

Conflicts of Interest: The authors declare no conflict of interest.

\section{References}

1. Li, X.; Xu, S.N.; Tan, Y.; Chen, J.P. The effects of idarubicin versus other anthracyclines for induction therapy of patients with newly diagnosed leukaemia. Cochrane Database Syst. Rev. 2015, 6, CD010432. [CrossRef]

2. Ganzina, F.; Pacciarini, M.A.; Di Pietro, N. Idarubicin (4-demethoxydaunorubicin). A preliminary overview of preclinical and clinical studies. Investig. New Drugs 1986, 4, 85-105. [CrossRef]

3. Rayner, D.M.; Cutts, S.M. Anthracyclines. Side Eff. Drugs Annu. 2014, 36, 638-694.

4. Lotfi, K.; Zackrisson, A.-L. Comparison of idarubicin and daunorubicin regarding intracellular uptake, induction of apoptosis, and resistance. Cancer Lett. 2002, 178, 141-149. [CrossRef]

5. Beretta, G.L.; Zunino, F. Molecular mechanisms of anthracycline activity. Top. Curr. Chem. 2008, 283, 1-19. [CrossRef]

6. Wei, X.; Huang, X.; Fang, Y.; Zhang, Q. Determination of idarubicin using CdTe quantum dots as fluorescence probes. J. Nanosci. Nanotechnol. 2016, 16, 6992-6997. [CrossRef]

7. Badea, I.; Lazar, L.; Moja, D.; Nicolescu, D.; Tudose, A. A HPLC method for the simultaneous determination of seven anthracyclines. J. Pharm. Biomed. Anal. 2005, 39, 305-309. [CrossRef]

8. Dehdashtian, S.; Behbahanian, N.; Taherzadeh, K.M.; Hashemi, B. Development of electrochemical sensor based on multiwall carbon nanotube for determination of anticancer drug idarubicin in biological samples. Adv. Nanochem. 2019, 1, 22-28. [CrossRef]

9. Dehdashtian, S.; Hashemi, B.; Chegeni, M.; Aeenmehr, A. The application of perlite/cobalt oxide/reduced graphene oxide (PC-rGO)/metal organic framework (MOF) composite as electrode modifier for direct sensing of anticancer drug idarubicin. IEEE Sensor. J. 2019, 19, 11739-11745. [CrossRef]

10. Pashaei, Y.; Mehrabi, M.; Shekarchi, M. A review on various analytical methods for determination of anthracyclines and their metabolites as anti-cancer chemotherapy drugs in different matrices over the last four decades. TrAC Trends Anal. Chem. 2020, 130, 115991. [CrossRef]

11. De la Cruz Morales, K.; Alarcón-Angeles, G.; Merkoçi, A. Nanomaterial-based sensors for the study of DNA interaction with drugs. Electroanalysis 2019, 31, 1845-1867. [CrossRef]

12. Topkaya, S.N.; Cetin, A.E. Electrochemical aptasensors for biological and chemical analyte detection. Electroanalysis 2020, 33, 277-291. [CrossRef]

13. Tadini-Buoninsegni, F.; Palchetti, I. Label-free bioelectrochemical methods for evaluation of anticancer drug effects at a molecular level. Sensors 2020, 20, 1812. [CrossRef]

14. Ozcelikay, G.; Karadurmus, L.; Kaya, S.I.; Bakirhan, N.K.; Ozkan, S.A. A review: New trends in electrode systems for sensitive drug and biomolecule analysis. Crit. Rev. Anal. Chem. 2020, 50, 212-225. [CrossRef]

15. Shoaie, S.; Daneshpour, M.; Azimzadeh, M.; Mahshid, S.; Khoshfetrat, S.M.; Jahanpeyma, F.; Gholaminejad, A.; Omidfar, K.; Foruzandeh, M. Electrochemical sensors and biosensors based on the use of polyaniline and its nanocomposites: A review on recent advances. Microchim. Acta 2019, 186, 465. [CrossRef]

16. Kulikova, T.N.; Porfireva, A.V.; Shamagsumova, R.V.; Evtugyn, G.A. Voltammetric sensor with replaceable polyaniline-DNA layer for doxorubicin determination. Electroanalysis 2018, 30, 2284-2292. [CrossRef] 
17. Mousavi, S.M.; Hashemi, S.A.; Bahrani, S.; Yousefi, K.; Behbudi, G.; Babapoor, A.; Omidifar, N.; Lai, C.W.; Gholami, A.; Chiang, W.-H. Recent advancements in polythiophene-based materials and their biomedical, geno sensor and DNA detection. Int. J. Mol. Sci. 2021, 22, 6850. [CrossRef]

18. Ghanbari, K.; Bathaie, S.Z.; Mousavi, M.F. Electrochemically fabricated polypyrrole nanofiber-modified electrode as a new electrochemical DNA biosensor. Biosens. Bioelectron. 2008, 23, 1825-1831. [CrossRef]

19. Porfireva, A.V.; Goida, A.I.; Rogov, A.M.; Evtugyn, G.A. Impedimetric DNA sensor based on poly(proflavine) for determination of anthracycline drugs. Electroanalysis 2020, 32, 827-834. [CrossRef]

20. Porfireva, A.; Vorobev, V.; Babkina, S.; Evtugyn, G. Electrochemical sensor based on poly(Azure B)-DNA composite for doxorubicin determination. Sensors 2019, 19, 2085. [CrossRef]

21. Porfireva, A.; Plastinina, K.; Evtugyn, V.; Kuzin, Y.; Evtugyn, G. Electrochemical DNA sensor based on poly(Azure A) obtained from the buffer saturated with chloroform. Sensors 2021, 21, 2949. [CrossRef]

22. Laube, N.; Mohr, B.; Hesse, A. Laser-probe-based investigation of the evolution of particle size distributions of calcium oxalate particles formed in artificial urines. J. Cryst. Growth 2001, 233, 367-374. [CrossRef]

23. Sha, Y.; Gao, Q.; Qi, B.; Yang, X. Electropolymerization of Azure B on a screen-printed carbon electrode and its application to the determination of NADH in a flow injection analysis system. Microchim. Acta 2004, 148, 335-341. [CrossRef]

24. Karyakin, A.A.; Karyakina, E.E.; Schmidt, H.-L. Electropolymerized azines: A new group of electroactive polymers. Electroanalysis 1999, 11, 149-155. [CrossRef]

25. Kanazawa, K.K.; Gordon, J.G. Frequency of a quartz microbalance in contact with liquid. Anal. Chem. 1985, 57, 1770-1771. [CrossRef]

26. Ozluer, C.; Kara, H.E.S. In vitro DNA binding studies of anticancer drug idarubicin using spectroscopic techniques. J. Photochem. Photobiol. B Biol. 2014, 138, 36-42. [CrossRef]

27. Tuite, E.; Nordén, B. Sequence-specific interactions of methylene blue with polynucleotides and DNA: A spectroscopic study. J. Am. Chem. Soc. 1994, 116, 7548-7556. [CrossRef]

28. Simerville, J.A.; Maxted, W.C.; Pahira, J.J. Urinalysis: A comprehensive review. Am. Fam. Physician 2005, 71, 1153-1162. 